\title{
Russula suecica, a new red species from Northern Fennoscandia
}

\author{
JUKKA VAURAS, JUHANI RUOTSALAINEN and KARE LIIMATAINEN
}

VAURAS, J., RUOTSALAINEN, J. \& LIIMATAINEN, K. 2016: Russula suecica, a new red species from Northern Fennoscandia. - Karstenia 56: 5-12. HELSINKI. ISSN 0453-3402.

Russula suecica, a new species occurring e.g. with species of Betula, is described and illustrated. It is known from Finland, Sweden, Norway, Canada, U.S.A. and Russia, from southern boreal zone to low-alpine belt. This species has fairly large fruit bodies, with red pileus, often with cream to whitish splodges, white stipe, often with reddish glimmer, very acrid taste, smell like Russula emetica, and creamy-yellow spore print.

Key words: Agaricales, Basidiomycetina, Fennoscandia, Russula, Russulales, taxonomy Jukka Vauras, Biological Collections of Ảbo Akademi University, Herbarium, FI-20014 University of Turku, Finland; e-mail: jukvau@utu.fi

Juhani Ruotsalainen (deceased)

Kare Liimatainen, Jodrell laboratory, Royal Botanic Gardens, Kew, Surrey, TW9 3AB, United Kingdom; e-mail: kare.liimatainen@helsinki.fi

\section{Introduction}

Many species in the genus Russula have red pileus, and therefore the identification of red Russula -species is often not easy. Here we add to the group a northern species, Russula suecica, which has earlier been provisionally called Russula clusii ss. Ruots. (Kytövuori et al. 2005).

\section{Material and methods}

Morphology. Spore masses from spore prints were placed between microscope slides, and colours were determined using Romagnesi's codes by the colour chart prepared by Christian Dagron. The measurements of the spores were made excluding ornamentation, and basidia lengts excluding sterigmata. The spores were measured in Melzer's reagent, other elements in $10 \%$ ammoniumhydroxide. $5 \%$ from each end of range of spores are given in parentheses.

Molecular analyses. DNA was extracted from dried material (pieces of lamellae) with the NucleoSpin Plant kit (Macherey-Nagel, Düren, Germany). Primers ITS 1F and ITS 4 (White et al. 1990, Gardes \& Bruns 1993) were used to amplify ITS regions and the same primer pairs were used in direct sequencing. Polymerase chain reaction amplification and sequencing followed Liimatainen et al. (2014).

Data analyses. Sequences were assembled and edited with Sequencher 4.1 (Gene Codes, Ann Arbor, Michigan, USA). For the phylogenetic analysis our own as well as the already published sequences of the genus were included. Using a BLAST query of the public databases (GenBank: http://www.ncbi.nlm.nih.gov/ and UNITE: http://unite.ut.ee/), we checked whether identical or similar sequences were in public databases. Lactarius trivialis (Fr.) Fr. (GenBank no. KT165317) and Lactarius torminosus (Schaeff.) Gray (GenBank no. KR025613) were used as an outgroup. The ITS alignment of 29 sequences was produced with the program MUSCLE (Edgar 2004) under default settings. The ITS alignment was manually adjusted in Seaview (Galtier et al. 1996). The alignment is composed of 750 nucleotides (including gaps). Sequences were subjected to Maximum Likelihood (ML) analysis as implemented in RAxML version 8 (Stamatakis 2014) with 1000 bootstrap replicates under the GTRGAMMA model. The phylogenetic tree resulting from our RaXML analysis is shown in Fig. 1. 


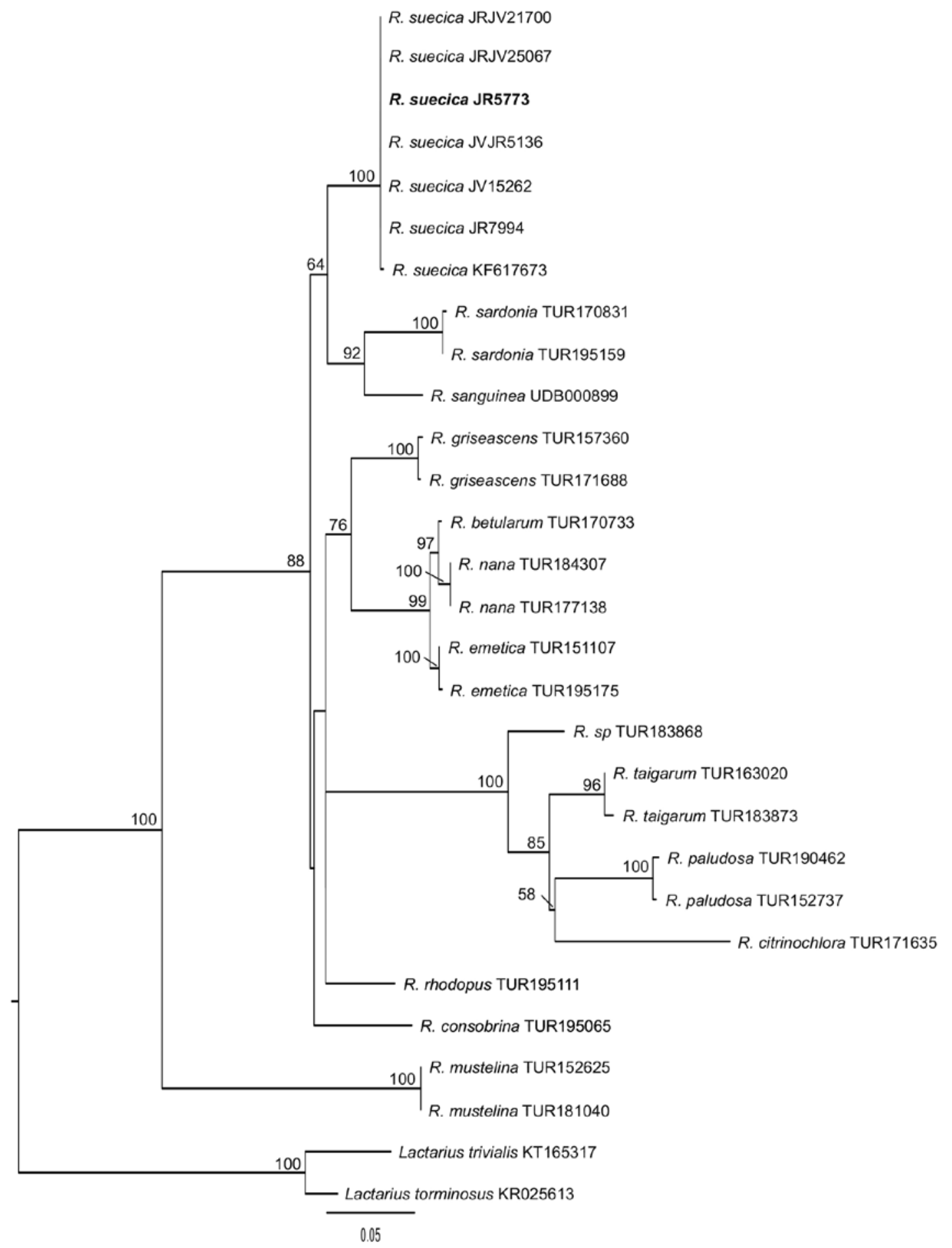

Fig. 1. Phylogram resulting from the RaXML analysis of ITS regions. Bootstrap values greater than $50 \%$ are indicated above branches. The sequence of Russula suecica originating from the type specimen is in boldface. 
Russula suecica Ruots. \& Vauras, sp. nova - Figs. 1-5

\section{MycoBank no.: MB 818674}

Diagnosis: Medium-sized to large species with red pileus, fading often partly or totally, with often irregular white stipe which can be partly reddish. Taste very acrid. Spores in mass pale crème to crème $(\mathrm{IIa}-\mathrm{c}),(7.1-) 7.8-9.3(-9.6) \times(6.4-$ )6.5-7.9(-8.2) $\mu \mathrm{m}$, mainly subglobose, with reticulum. Dermatocystidia mainly fusiform and often moniliform.

Typus: Sweden. Norrbotten. Övertorneå, Pello, W of Neistenkangas, near Yli-Tankovaara, moist brookside forest with Picea abies, Betula and Pinus sylvestris, alt. ca $110 \mathrm{~m}$ a.s.1., ca $66^{\circ} 47^{\prime} 30^{\prime \prime}$ N, 2347'30" E, 9.VIII.2001 Ruotsalainen $5773 F$ (KUO - holotype; GB, TUR-A - isotypes, GenBank no. KX099962).

Etymology: the species is dedicated to the memory of our late friend Juhani Ruotsalainen (his Finnish family name means "Swedish", hence "suecica"). The holotype specimen selected also originates from Sweden.

Pileus $3-12 \mathrm{~cm}$ in diam, at first plano-convex to convex, sometimes with low umbo, later expanded and depressed, often somewhat irregular, margin deflexed, often undulate, blunt, first smooth, later slightly sulcate; scarlet, but mostly not as intensive as $R$. emetica or $R$. nana, often darkest at centre, pale red, sometimes already when young with pale areas, later, when washedout, with whitish, crème, pale brownish and/or pale greenish colors, surface when moist viscid, when dry mostly shiny, not pruinose, ca half of pileipellis peeling. Lamellae up to $10 \mathrm{~mm}$ broad, moderately crowded, adnate to subdecurrent, at first white, then cream-white, later cream-yellow to pale yellow, with some shade of greyish, with many bifurcations and lamellulae, fragile, taste very acrid. Stipe $3-11 \times 1.2-3 \mathrm{~cm}$, subclavate or thickest at the middle, often irregular and with knobs, longitudinally somewhat rugose, not pruinose, not hollow inside; when young white or often partly reddish, later somewhat greyish and with yellow-brown to brown patches. Context white to whitish to weakly yellowish, when old partly yellow-brown, under pileipellis pale red, fairly soft; taste acrid to very acrid. Odour fruity or somewhat like in cocoa (like R. emetica).
Spores in mass pale creme to creme (Romagnesi IIa-c), $(7.1-) 7.8-8.5-9.3(-9.6) \times(6.4-) 6.5-7.3-$ $7.9(-8.2) \mu \mathrm{m}$, total range of mean values $7.9-8.8$ $\times$ 7.0-7.6 $\mu \mathrm{m}, \mathrm{Q}=(1.05-) 1.1-1.17-1.25(-$ 1.3), total range of mean $Q$ values $1.13-1.20$ (140 spores from 7 collections); subglobose to broadly ellipsoid, amyloid, with rather dense, \pm complete reticulum, warts up to $0.8 \mu \mathrm{m}$ long, blunt, plage amyloid. Basidia 32-45 × 7-10 $\mu \mathrm{m}$, clavate, 4-spored. Hymenial cystidia 8-11 $\mu \mathrm{m}$ broad, blunt to appendiculate. Pileipellis: apical cells 2-4 $\mu \mathrm{m}$ broad, clavate to cylindrical, dermatocystidia 4-7 $\mu \mathrm{m}$ broad, 0-3(-7) septate, mainly fusiform, often moniliform and with appendix, a part cylindrical, some subclavate, without encrusted elements, fairly scarce to moderately numerous. In the ITS regions $R$. suecica is distinct from other known Russula species and differs from $R$. sardonia $\mathrm{Fr}$. and $R$. sanguinea $\mathrm{Fr}$. over 45 substitutions and indel positions ( $>7 \%$ ).

Russula suecica has a wide distribution in Fennoscandia. In Sweden and Finland it has a northoriented distribution with occurrences mainly in middle and northern boreal zone, and also in oroarctic zone. In Norway the southernmost localities are near the limit of the hemiboreal (boreonemoral) zone, but on higher altitude. Further, the species is known from Northern Russia and low arctic tundra of Canada.

In boreal forests Russula suecica grows often in fairly old mixed forests dominated by $\mathrm{Pi}$ cea abies, very often on foots of slopes of hills, on bottoms of gorges, at margins of paludified brooksides, at margins of bogs, also in Sphagnum or close to it. These forest sites have rather cool soils. Further, it grows in subalpine birchwoods of Betula pubescens subsp. czerepanovii, and in low-alpine belt, where it can be found amongst Betula nana. In Russia it has been collected from mossy heath tundra near Betula nana and Salix, in Canada in low arctic tundra with e.g. Salix arctica and S. herbacea, but also with Rhododendron and Arctostaphylos, without any Salix or Betula nearby. According to data in GenBank and UNITE Database it occurs in Canada and U.S.A., Alaska with e.g. Betula nana and Salix arctica. According to this data the species has a broad distribution. Maybe it is not a rare species, because it seems not to be particularly demanding.

The fruiting period of $R$. suecica starts in early August, reaches the maximum in mid-August - late August, and ceases in mid-September. 


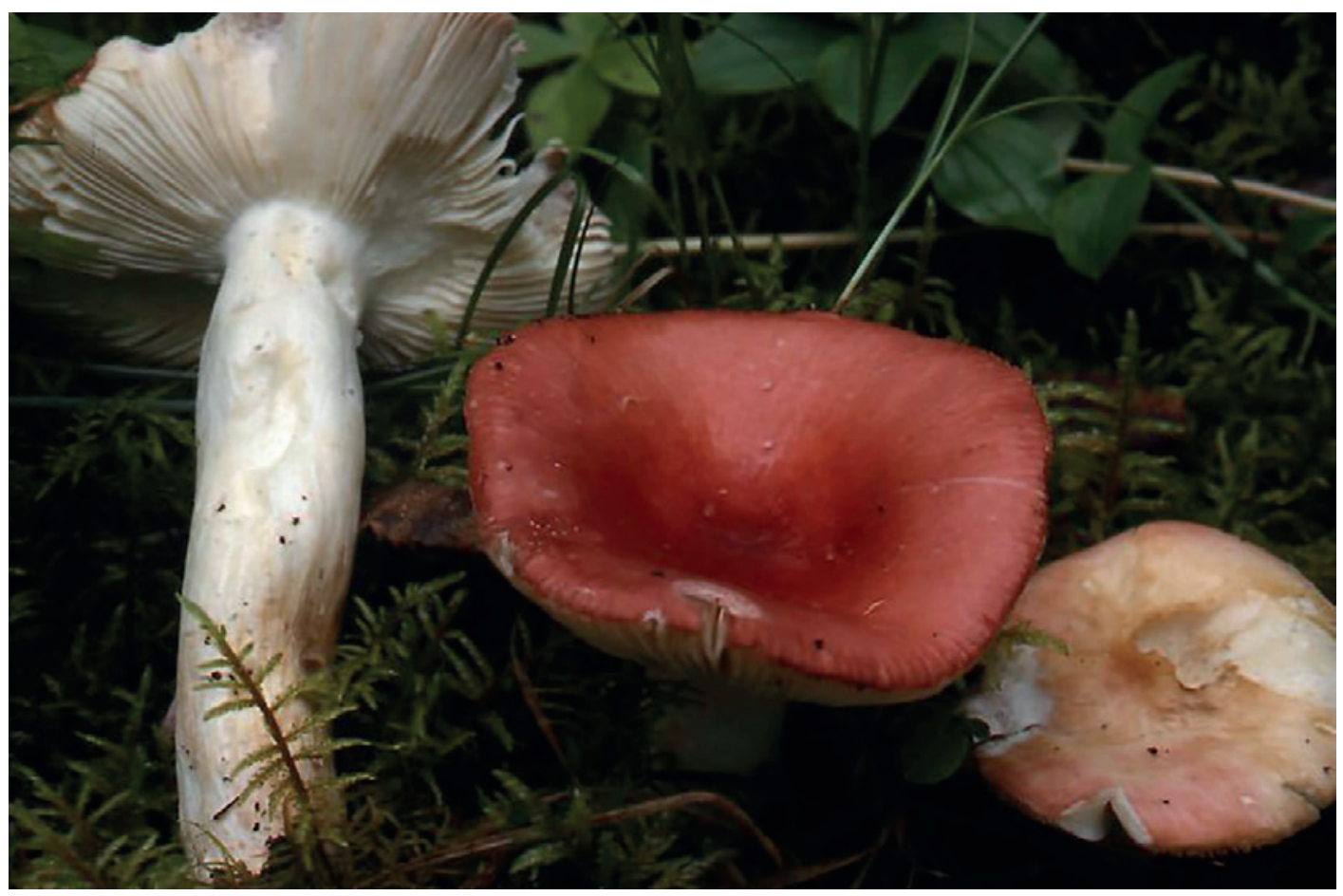

Fig. 2. Russula suecica, holotype (Ruotsalainen 5773F). Photo: J. Ruotsalainen.

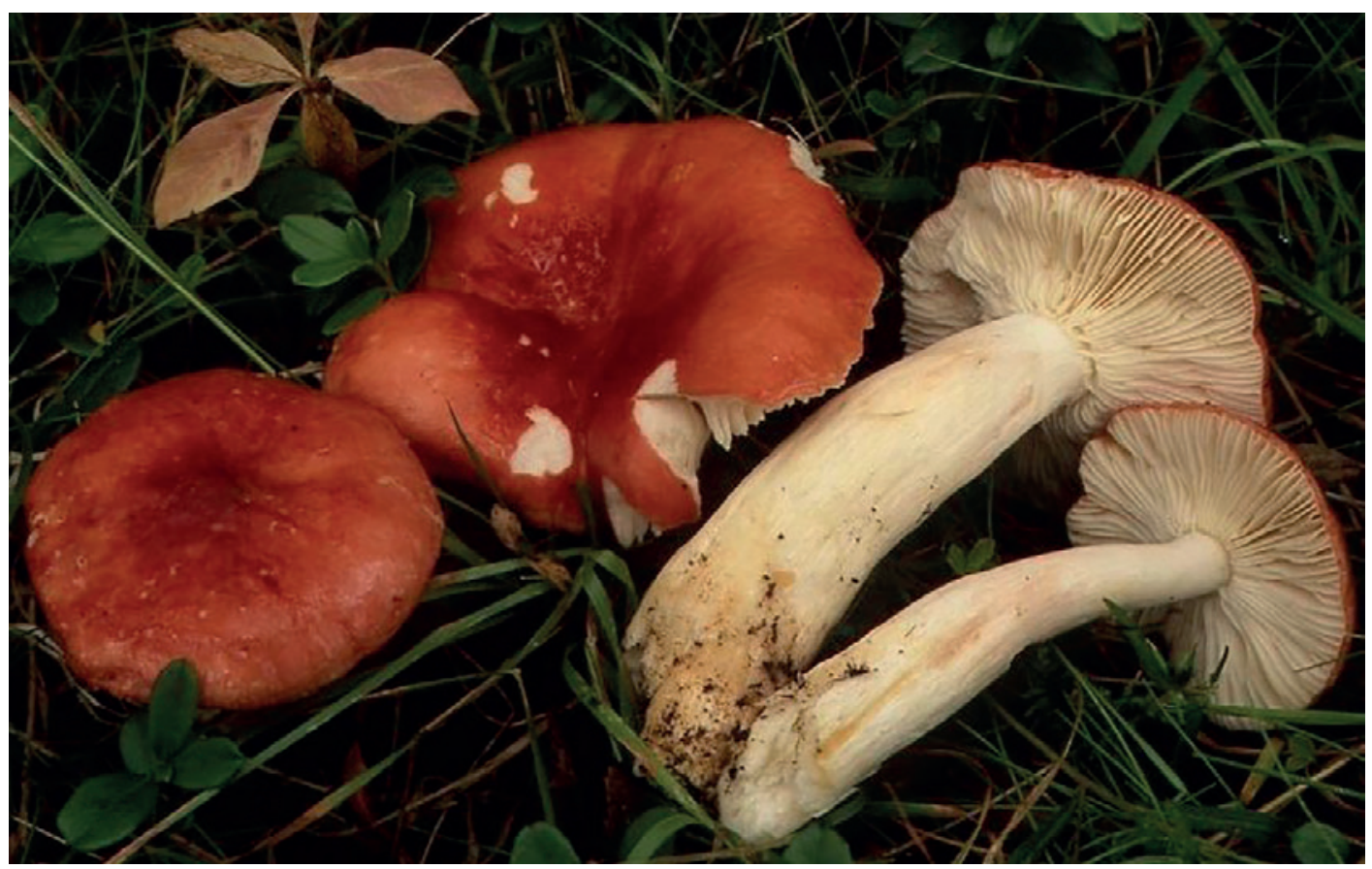

Fig. 3. Russula suecica, Norway, Troms, Storfjord, Lulledalen, 17.VIII.2004 Ruotsalainen \& Vauras 21700F. - Photo: J. Vauras. 


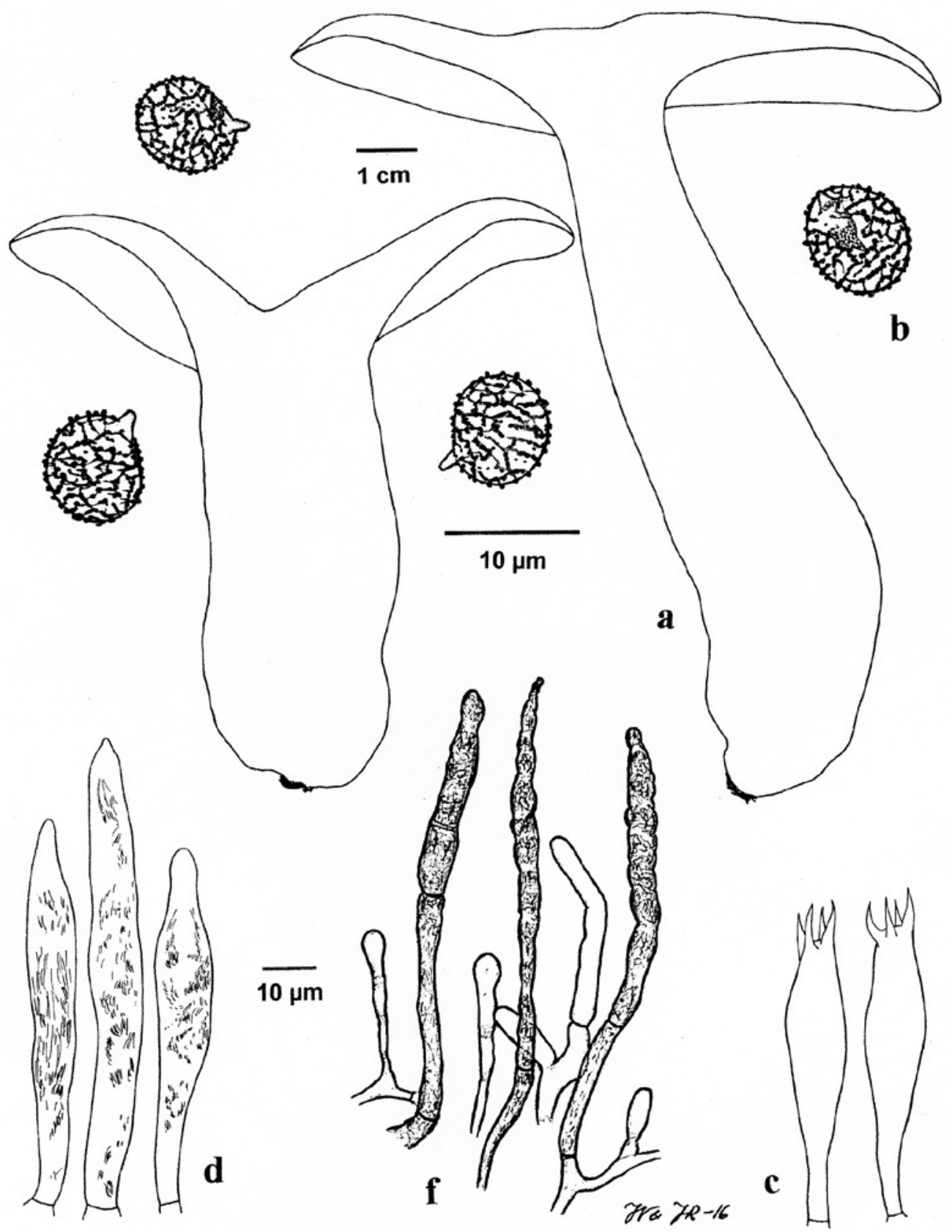

Fig. 4. Russula suecica. Cross-sections of fruit bodies (a) and microscopical characters $(\mathrm{b}=\mathrm{spores}, \mathrm{c}=\mathrm{basidia}, \mathrm{d}$ $=$ hymenial cystidia, e = elements of pileipellis). All from holotype but cross-sections from Ruotsalainen \& Vauras $21700 F$. 
Other specimens studied: CANADA. Nunavut. Baker Lake, ca. $2 \mathrm{~km}$ NE of the settlement, 14.VIII.1974/5 Ohenoja (OULU), ca $2 \mathrm{~km}$ NNW of the settlement, 18.VIII.1974/96 Ohenoja (OULU); Rankin Inlet, Kudlulik Peninsula, near NW end of the airstrip, 21.VIII.1971/36 Ohenoja (OULU). FINLAND. Pohjois-Häme. Konnevesi, Hytölä, Myllykorpi, 6.IX.2002 Ruotsalainen 6129 (KUO). Pohjois-Savo. Kuopio, Neulaniemi, 23.VIII.1980 Vauras 722 (TURA), 10.VIII.1988 Heikkilä, Vauras \& Ruotsalainen 1046F (KUO), 11.VIII.1994 Vauras \& Ruotsalainen 3521 (KUO); Nilsiä, Tahkomäki, Huutavanholma, 4.IX.1994 Aho \& Ruotsalainen 3748 (KUO), 17.VIII.1998 Ruotsalainen 4765F (KUO), 17.VIII.1999 Aho \& Ruotsalainen 5194 (KUO); Leppävirta, Mustinmäki, Orinnoro, 19.VIII.2000 Ruotsalainen 5580 (KUO), 19.VIII.2001 Ruotsalainen 5817 (KUO). Pohjois-Karjala. Liperi, Leppälahti, 28.VIII.1994 Höijer 1269 (KUO), Siikasaari, 27.VIII.1994 Ruotsalainen 3684 (KUO, TUR-A). Oulun Pohjanmaa. Pudasjärvi, Iinattijärvi, Ohtavaara, 22.VIII.1997 Ohenoja (OULU, H). PeräPohjanmaa. Rovaniemi, Pahtaja, 21.VIII.1999 Kuusela (TUR-A), Sinettä, near Pohtimolampi, 2.IX.2013 Kytövuori (KUO), Taipale, Kalkkimaa, 21.VIII.1999 Vauras 15262 (TUR-A; UNITE no. UDB022609); Tuhnaja, Kiimamaa, 6.IX.2013 Ruotsalainen 9092 (KUO, TUR-A). Koillismaa. Kuusamo, Hiltunen, Iivaara, E slope, 29.VIII.2007 Ruotsalainen \& Vauras 25067 (TUR-A, UNITE no. UDB022610), Kouvervaara, 23.VIII.1997 Ruotsalainen 4430 (KUO), Oulanka National Park, Jäkälävaara, 21.VIII.1997 Ruotsalainen 4397, 4407 (KUO), 30.VIII.1998 Ruotsalainen 4782F (KUO), 26.VIII.2002 Ruotsalainen 6087 (KUO), Nurmisaarenniemi, 23.VIII.2007 Vauras 24948 (TUR-A), 27.VIII.2007 Alpago-Novello (KUO), Salminen, 23.VIII.1997 Ruotsalainen 4423 (KUO, TURA), Vuotunki, Kuntivaara, 2.IX.2005 Ruotsalainen 7105 (KUO, O). Kittilän Lappi. Kolari, Teuravuoma, 6.VIII.1986 Ruotsalainen 257F (KUO, TUR-A). Sompion Lappi. Sodankylä, Luosto, Luostonloma, 27.VIII.2008 Vauras \& Ruotsalainen 7756 (KUO), Urho Kekkonen National Park, Pyhä-Nattanen, 23.VIII.1990 Kytövuori 90-588 (H). Enontekiön Lappi. Enontekiö, Kaaresuvanto, 11.VIII.1985 Vauras \& Ruotsalainen 64 (KUO); Kilpisjärvi, Goallarrássa, 14.VIII.1990 Vauras \& Ruotsalainen
1783 (KUO); Pikku-Malla, 9.VIII.1986 Vauras \& Ruotsalainen 283 b (TUR-A), Possovárri, 20.VIII.2014 Lahti (KUO), Siilasvuoma, 25.VIII.2014 Ruotsalainen 9202 (KUO). NORWAY. Akershus. Nittedal, Åneby, 25.VIII.2000 Eggen (TUR-A). Buskerud. Ringerike, Hönefoss, Grunntjern, 28.VIII.2003 Ruotsalainen $6361 b$ (KUO), 16.VIII.2006 Marstad 12209 (O). Sör-Tröndelag. Åtfjord, Stordalen, Latanger, 4.IX.2009 Ruotsalainen 8002 (KUO). Nord-Trøndelag. Steinkjer, Mokk, 3.IX.2009 Ruotsalainen 7994 (H, KUO, GenBank no. KX988014). Troms. Storfjord, Bossovarri near border of Finland, Campo \& Lahti 57/14 (TUR), Lulledalen, 17.VIII.2004 Ruotsalainen \& Vauras $21700 F$ (TUR-A, KUO, GenBank no. KX988015), 22.VIII.2014 Ruotsalainen 9176 (KUO), Övrevatnet, 19.VIII.2004 Ruotsalainen 6649 (KUO). RUSSIA. Tumen Region. Yamalo-Nenetsia, E part of Bolshemelska Tundra, W of the estuary of Talatayakha River, 20.VIII.1996 Ohenoja (OULU). SWEDEN. Ångermanland. Säbro, Håltjärnsberget, 27.VIII.1997 Kytövuori (KUO). Lule lappmark. Jokkmokk, Padjelanta National Park, Svartinjunjes, 19.VIII.2016 Vauras 31586F (TUR-A, GB). Norrbotten. Övertorneå, Pello, 12.VIII.1999 Vauras \& Ruotsalainen 5136F (KUO, TUR-A, GenBank no. KX099961), 21.VIII.2016 Vauras 31629 (TURA). Torne lappmark. Jukkasjärvi, Björkliden, 17.VIII.1999 Ruotsalainen 5161 (KUO), Riksgränsen, 26.VIII.2016 Cатро (TUR-A).

\section{Discussion}

As a red-capped species Russula suecica is not very easy to recognize in the nature. According to its macroscopical and microscopical characters the species belongs to subsection Sardoninae Singer. Among them it could be taken as e.g. $R$. rhodopus Zvara, $R$. helodes Melzer, $R$. renidens Ruots., Sarnari \& Vauras or $R$. depallens (Pers.: Fr.) Fr. These species have somewhat darker spores in mass. Further, $R$. rhodopus is a species growing with Picea abies. Its spores have not as dense and complete reticulum, and they are somewhat smaller. $R$. helodes seems to be a rare or very rare species in the Nordic countries. It has larger spores than $R$. suecica. $R$. renidens grows on wet sites with Betula. Its pileus has different tone of red, i.e. blood red to violaceous 


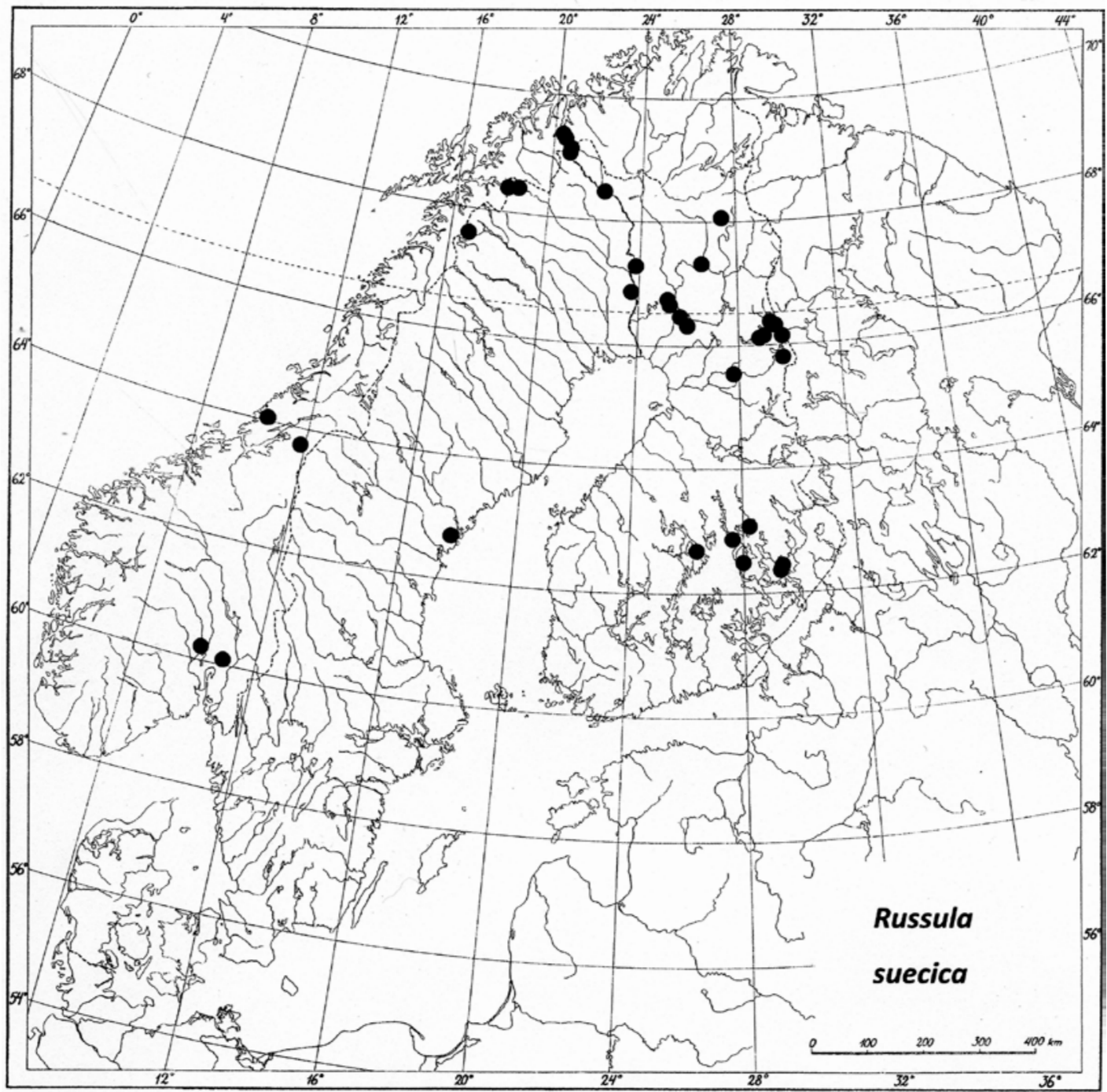

Fig. 5. Distribution of Russula suecica in Fennoscandia, according to the material examined.

purple, and spores are verrucose, with some connections. $R$. depallens grows with Betula on dry calcareous grounds, as at roadsides. Its spores are not as reticulated as in $R$. suecica.

Russula suecica somewhat resembles also $R$. emetica (Schaeff.: Fr.) Pers., R. nana Killerm. and $R$. griseascens (Bon \& Gaugué) Marti, all members of subsection Russula (= Emeticinae Melzer \& Zvara ss. Romagnesi; Sarnari 1998). These species are somewhat smaller than $R$. suecica, and their spores are in mass white to whitish. R. emetica and $R$. nana have bright-red pileus and white stipe. $R$. griseascens has a graying stipe, rarely with a pink tinge. For more characters of the species used in comparison with $R$. suecica we refer to Sarnari (1998).

The name Russula clusii Fr. is difficult to interpret (Sarnari 1998). Fries (1838) gives a very short description, cites some older literature and states: "Mihi parum cognate." (= a species too little known by me). At the moment we prefer to regard this as a dubious name. 
Acknowledgements: We thank Ellen Larsson for her kind work with sequences of an isotype and a paratype. Mika Toivonen has helped with important discussions during the writing work of this article. We thank Mauro Sarnari and Emanuele Campo for their opinions about the taxon described here. Curators of herbaria $\mathrm{H}, \mathrm{O}$ and OULU are gratefully acknowledged for arranging loans. We thank all friends who have given their collects to our use. Financial support was received from Ministry of Environment, Finland (YM38/5512/2009), and through the FinBOLproject funded by the Finnish Cultural Foundation and Kone Foundation.

\section{References}

Edgar, R.,C. 2004: MUSCLE: multiple sequence alignment with high accuracy and high throughput. - Nucleic Acids Research 32: 1792-1797.

Fries, E. 1838: Epicrisis systematis mycologici. -610 pp. Upsaliae.

Galtier, N., Gouy, M., Gautier, C. 1996: SEAVIEW and PHYLO WIN: two graphic tools for sequence alignment and molecular phylogeny. - Bioinformatics 12(6): 543-548.

Gardes, M., Bruns, T.,D. 1993: ITS primers with enhanced specificity for basidiomycetes - application to the identification of mycorrhizae and rusts. - Molecular Ecology 2: 113-118.

Kytövuori, I., Nummela-Salo, U., Ohenoja, E., Salo, P. \& Vauras, J. 2005: Helttasienten ja tattien levinneisyystaulukko. Distribution table of agarics and bolets in Finland. \& Helttasienten ja tattien ekologiataulukko. Ecology table of agarics and bolets in Finland. - In: Salo, P., Niemelä, T., Nummela-Salo, U. \& Ohenoja, E. (eds.). Suomen helttasienten ja tattien ekologia, levinneisyys ja uhanalaisuus. Suomen ympäristökeskus. Helsinki. Suomen ympäristö 769: 109-426.

Liimatainen, K., Niskanen, T., Dima, B., Kytövuori, I., Ammirati, J.F. \& Frøslev, T. 2014: The largest type study of Agaricales species to date: bringing identification and nomenclature of Phlegmacium (Cortinarius, Agaricales) into the DNA era. - Persoonia 33: 98-140.

Sarnari, M. 1998: Genere Russula in Europa 1. - 799 pp. A.M.B. Fondazione Centro Studi Micologici, Trento.

Stamakis, A. 2014: RAxML Version 8: A tool for Phylogenetic analysis and Post-Analysis of Large Phylogenies. - Bioinformatics 30: 1312-1313.

White, T.J., Bruns, T.D., Lee, S. \& Taylor, J.W. 1990: Amplification and direct sequencing of fungal ribosomal RNA genes for phylogenetics. - In Innis, M.A., Gelfand, D.H., Snisky, J.J. \& White, T.J. (eds.). PCR protocols: a guide to methods and applications. Academic Press, Inc., New York. pp. 315-322. 